\title{
Efficacy of Staphylococcus aureus Vaccine in Chicken
}

\author{
Abeer S. El-Maghraby1*, Shereanaziz² and AbeerMwafy ${ }^{3}$ \\ ${ }^{1}$ Central Laboratory for Evaluation of Veterinary Biologics, Abbasia, Cairo, Egypt. \\ ${ }^{2}$ Veterinary Serum and Vaccine Research Institute (VSVRI), Abbassia, Cairo, Egypt. \\ ${ }^{3}$ Department of Microbiology, Faculty of Veterinary Medicine, El-Wady El-Gaded University, Cairo, Egypt. \\ "Corresponding author's Email: abeer.maghraby17774@ gmail.com; ORCID: 0000-0002-4217-0206
}

Received: 12 Feb. 2020

Accepted: 23 Mar. 2020

\begin{abstract}
Staphylococcus aureus is considered one of the most important pathogens causing septic arthritis in poultry with significant economic losses. This study aimed to evaluate the efficacy of a locally prepared $S$. aureus vaccine against staphylococcal arthritis in poultry. Out of 78 samples collected from infected chickens showing clinical signs bumble foot, 10 field isolates were detected and confirmed phenotypically by culturing, Gram staining, biochemical and molecular identification to be $S$. aureus in prevalence of $12.82 \%$. Molecular identification of clumping factor A (ClfA) and blaZ genes of $S$. aureus isolates revealed that the PCR amplification with ClfA and blaZspecific primers conducted with genomic DNA resulted in products of approximate size $638 \mathrm{bp}$ and $833 \mathrm{bp}$, respectively. Phylogenetic tree for $S$. aureus $C l f A$ virulence gene partial sequences was generated using maximum likelihood, neighbour joining and maximum parsimony in MEGA6. It showed clear clustring of Egyptian isolated strain $(S$. aureus ASM strain) and different $S$. aureus strains uploaded from GenBank. Sequence identities between the Egyptian isolated strain ( $S$. aureus ASM strain)and different $S$. aureus strains uploaded from GenBank revealed $99.5 \%$ to $100 \%$ homology. Also, there was identity and homology in S. aureusblaZgene nucleotide sequence in the Egyptian isolated strain ( $S$. aureus ASM strain)and the different $S$. aureus strains uploaded from GenBank revealed $96.1 \%$ to $98.9 \%$ homology. Phylogenetic tree for $S$. aureusblaZß-lactamases resistant gene partial sequences showed clear clustring of the Egyptian isolated strain (S. aureus ASM strain)and different $S$. aureus strains uploaded from GenBank. The results of humoral immune response revealed that the geometric mean antibody values against locally prepared $S$. aureus vaccine measured by indirect hemagglutination test increased from $1^{\text {st }}$ week post vaccination gradually till reached maximum level $(322.5)$ at $6^{\text {th }}$ week post boostering. The results showed an increased humoral antibody production in vaccinated group that was capable of preventing establishment of new $S$. aureus infection in vaccinated group compared to control group. The mortality rates in unvaccinated group was higher than that of vaccinated group were $(42.5 \%$, vs. $7.5 \%)$ at $1^{\text {st }}$ and $2^{\text {nd }}$ week post challenge $(39.1 \%$ vs. $5.4 \%)$. The protection $\%$ in challenge assay of the prepared $S$. aureus vaccine was $(92.5 \%$ and $87.5 \%)$ at $1^{\text {st }}$ and $2^{\text {nd }}$ week post challenge respectively. It could be concluded that the prepeared vaccine was safe, potent and protect birds against $S$. aureus infection.
\end{abstract}

Key words: Blaz, ClfA, PCR, Sequencing, Staphylococcus aureus, Vaccine.

\section{INTRODUCTION}

Staphylococcus aureus is regarded as one of the most prevalent pathogens that can cause great economic losses in poultry sector. In poultry, S. aureus causes many clinical syndromes as tenosynovitis, omphalitis, femoral head necrosis, bumble foot, infected hock and stifle joints (Sulemian et al., 2013). Different antimicrobial agents such as $\beta$-lactamases, macrolides, aminoglycosides and tetracyclines are extensively used in poultry for treating of staphylococci and other infections which lead to development of drug resistant strains of bacteria (Nemati et al., 2008). Resistance to penicillin as developed by staphylococci is mediated by two mechanisms: either by the secretion of an $\beta$-lactamases enzyme, encoded by the blaZ gene in plasmid or chromosome, which inactivates the antibiotic by hydrolysis of its $\beta$-lactam ring, or by the production of a penicillin binding protein (PBP2A) encoded by gene mecA (Liu, 2009). The need for $S$. aureus vaccine was mainly determined by the economic loss in poultry farming resulting from arthritis in poultry Fluit et al. (2012). Prophylaxis via prevention of infection by using antibiotics is of low fee in case of antibiotic resistant strains, as penetration through the infected joints no way for theraby of arthritis caused by $S$. aureus. Vaccination is the solely way for protection against staphylococcal arthritis in poultry. The main objective of this study was to evaluate the efficacy of a 
locally prepared $S$. aureus vaccine against staphylococcal arthritis in poultry.

\section{MATERIALS AND METHODS}

\section{Ethical approval}

The Institutional Animal Care and Use Committee (IACUC) has approved animal use protocol used in this study (Vet. CU. 20022020146).

\section{Samples collection and isolation of Staphylococcus aureus}

A total of 78 samples (46 samples from layers farms and 32 samples from broiler farms) were collected from private poultry farms in Sharkia, Qalubia, Behira and Dakahlia governorates, Egypt. The samples taken from birds having swollen hock joints, wings and foot pads. These samples were taken under aseptic conditions according to Jordan et al. (2002). Isolation of S. aureus was obtained by culturing these samples on tryptic soy broth (TSB) containing $70 \mathrm{mg} / \mathrm{ml} \mathrm{NaCl}$, then culturing from this broth on blood agar, mannitol salt agar, and
Baird Parker agar media then incubated at $37^{\circ} \mathrm{C}$ for $24 \mathrm{~h}$., according to Quinn et al. (2002).

\section{Identification of Staphylococcus aureus isolates}

Isolated colonies of $S$. aureus were identified by classical identification as microscopical examination, biochemical reactions using API-Staph system (Table 1) and pathogenicity test according to Quinn et al. (2002), Taponen et al. (2008), López-Malo et al. (2005), El- jakee et al. (2013), Kateete et al. (2010) and Toply and Wilsons (1993). Phenotypic characterization of the same isolation was applied to detect coagulase test according to Quinn et al. (2002), and hemolysis assay according to Koneman et al. (1997).

Molecular identification of Staphylococcus aureus All the identified $S$. aureus isolates were examined by PCR for the presence of clumping factor A (ClfA) virulence associated gene then detected the presence of $S$. aureus (blaZ) gene in all field isolates. The primers sequences and PCR product sizes are shown in table 2.

Table 1. Results of biochemical identification of Staphylococcus aureususing API-Staph system

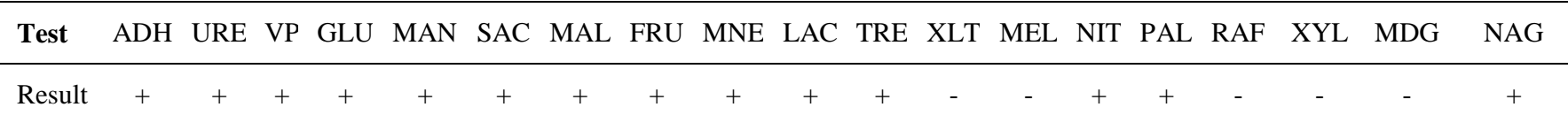

(ADH) L-arginine, (URE) urea, (VP) VogusProskour, (GLU) D-glucose, (MAN) D-mannitol, (SAC) D-sucrose, (MAL) D-maltose, (FRU) D-fructose, (MNE) D-mannose, (LAC) D-lactose, (TRE) D-trehalose, (XLT) Xylitol, (MEL) D-melibiose, (NIT) Nitrate potassium, (PAL) L-B-naphtyl phosphate, (RAF) D-raffinose, (XYL) D-xylose, (MDG) methyl D-glucopyranoside, (NAG) N-acetyl-glucosamine.

Table 2. Primerssequences, target genes, amplicon sizes and cycling conditions.

\begin{tabular}{|c|c|c|c|c|c|c|c|c|}
\hline \multirow{2}{*}{$\begin{array}{l}\text { Target } \\
\text { gene }\end{array}$} & \multirow[b]{2}{*}{ Primers sequences $\left(5^{\prime}--3^{\prime}\right)$} & \multirow{2}{*}{$\begin{array}{l}\text { Amplified } \\
\text { segment } \\
\text { (base pair) }\end{array}$} & \multirow{2}{*}{$\begin{array}{c}\text { Primary } \\
\text { denaturation }\end{array}$} & \multicolumn{3}{|c|}{ Amplification ( 35 cycles) } & \multirow{2}{*}{$\begin{array}{c}\text { Final } \\
\text { extension }\end{array}$} & \multirow[b]{2}{*}{ Reference } \\
\hline & & & & $\begin{array}{c}\text { Secondary } \\
\text { denaturation }\end{array}$ & Annealing & Extension & & \\
\hline \multirow{2}{*}{ ClfA } & F:GCAAAATCCAGCACAACAGGAAACGA & \multirow[t]{2}{*}{638} & \multirow{2}{*}{$\begin{array}{c}94^{\circ} \mathrm{C} \\
5 \mathrm{~min} .\end{array}$} & \multirow{2}{*}{$\begin{array}{c}94^{\circ} \mathrm{C} \\
30 \mathrm{sec} .\end{array}$} & \multirow{2}{*}{$\begin{array}{c}55^{\circ} \mathrm{C} \\
40 \mathrm{sec} .\end{array}$} & \multirow{2}{*}{$\begin{array}{l}72^{\circ} \mathrm{C} \\
45 \mathrm{sec} .\end{array}$} & \multirow{2}{*}{$\begin{array}{l}72^{\circ} \mathrm{C} \\
10 \mathrm{~min} .\end{array}$} & \multirow{2}{*}{$\begin{array}{l}\text { Mason et } \\
\text { al.(2001) }\end{array}$} \\
\hline & R: CTTGATCTCCAGCCATAATTGGTGG & & & & & & & \\
\hline \multirow{2}{*}{ blaZ } & F:TACAACTGTAATATCGGAGGG & \multirow{2}{*}{833} & \multirow{2}{*}{$\begin{array}{l}94^{\circ} \mathrm{C} \\
5 \mathrm{~min} .\end{array}$} & \multirow{2}{*}{$\begin{array}{c}94^{\circ} \mathrm{C} \\
30 \mathrm{sec} .\end{array}$} & \multirow{2}{*}{$\begin{array}{c}50^{\circ} \mathrm{C} \\
40 \mathrm{sec} .\end{array}$} & \multirow{2}{*}{$\begin{array}{c}72^{\circ} \mathrm{C} \\
50 \mathrm{sec}\end{array}$} & \multirow{2}{*}{$\begin{array}{c}72^{\circ} \mathrm{C} \\
10 \mathrm{~min}\end{array}$} & \multirow{2}{*}{$\begin{array}{l}\text { Bagcigilet } \\
\text { al. (2012) }\end{array}$} \\
\hline & R:CATTACACTCTTGGCGGTTTC & & & & & & & \\
\hline
\end{tabular}

\section{DNA extraction}

DNA extraction from samples was performed using the QIAamp DNA Mini kit (Qiagen, Germany, GmbH) with modifications from the manufacturer's recommendations. Briefly, $200 \mu \mathrm{l}$ of the sample suspension was incubated with $10 \mu 1$ of proteinase $\mathrm{K}$ and $200 \mu \mathrm{l}$ of lysis buffer at $56^{\circ} \mathrm{C}$ for $10 \mathrm{~min}$. After incubation, $200 \mu \mathrm{l}$ of $100 \%$ ethanol was added to the lysate. The sample was then washed and centrifuged following the manufacturer's recommendations. Nucleic acid was eluted with $100 \mu$ l of elution buffer.

\section{Oligonucleotide Primer}

Primers used were supplied from Metabion (Germany) are listed in Table 2.

\section{PCR amplification}

Primers were utilized in a $25-\mu 1$ reaction containing $12.5 \mu 1$ of EmeraldAmp Max PCR Master Mix (Takara, Japan), $1 \mu 1$ of each primer of 20 pmol concentration, 4.5 $\mu 1$ of water, and $6 \mu 1$ of DNA template. The reaction was performed in an applied biosystem 2720 thermal cycler. 


\section{Analysis of the PCR products}

The products of PCR were separated by electrophoresis on $1.5 \%$ agarose gel (Applichem, Germany, GmbH) in 1x TBE buffer at room temperature using gradients of $5 \mathrm{~V} / \mathrm{cm}$. For gel analysis, $20 \mu \mathrm{l}$ of the products was loaded in each gel slot. Generuler $100 \mathrm{bp}$ ladder (Fermentas, Thermo, Germany) was used to determine the fragment sizes. The gel was photographed by a gel documentation system (Alpha Innotech, Biometra) and the data was analyzed through computer software.

Phylogenetic and gene sequence analysis of ClfA andblaZ genes of Staphylococcus aureus

PCR products were purified using QIAquick PCR Product extraction kit. (Qiagen, Valencia). Bigdye Terminator V3.1 cycle sequencing kit (Perkin-Elmer) was used for the sequence reaction and then it was purified using Centrisep spin column. DNA sequences were obtained by Applied Biosystems3130 genetic analyzer (HITACHI, Japan), a BLAST® analysis (Basic Local Alignment Search Tool) (Altschul et al., 1990) was initially performed to establish sequence identity to Gen Bank accessions. The phylogenetic tree was created by the MegAlign module of Laser gene DNA Star version 12.1 (Thompson et al., 1994) and Phylogenetic analyses was done using maximum likelihood, neighbor joining and maximum parsimony in MEGA6 (Tamura et al., 2013).

\section{Vaccination and challenge test Vaccine preparation}

The vaccine was prepared according to the methods described by Giraudo et al. (1997), Ahmad and Muhammad (2008) and Raza et al. (2015). From the complete identified isolated Egyptian strain ( $S$. aureus ASM strain), $10 \mathrm{ml}$ from the freshly preperaed culture was streaked on brain-heart infusion agar and incubated at $37^{\circ} \mathrm{C}$ for $18 \mathrm{~h}$ Then, the strain was separately subcultured in brain-heart infusion at $37^{\circ} \mathrm{C}$ for $24 \mathrm{~h}$.

Preparation of $S$. aureusbacterin in liquid medium: A culture of well identified strain was prepared from single colony which was scaled up to one TSB medium. Also preparation of $S$. aureusbacterin on solid medium by cultivation of single colony on BHI agar or TS agar then incubated at $37^{\circ} \mathrm{C}$ for $24 \mathrm{~h}$ The bacterial suspension was centrifuged at $\left(3000 \mathrm{rpm}\right.$ at $4^{\circ} \mathrm{C}$ for $\left.30 \mathrm{~min}\right)$ to pellet the bacterial cells, after that the bacterial pellets washed and resuspended in $0.15 \mathrm{~mol} / \mathrm{l} \mathrm{PBS}(\mathrm{pH}$ 7.2). The culture suspension was examined for purity through Gram's stain method and by streaked on blood agar. The colony forming unit was determined by plate counting and bacterial concentrations was adjusted to contain $1 \times 109$ cells/ml (Raza et al., 2015). The $S$. aureus toxin was prepared by taking $10 \mathrm{ml}$ of freshly prepared working solution and incubated into $500 \mathrm{ml}$ of BHI, then incubated at $37^{\circ} \mathrm{C}$ for $48 \mathrm{~h}$. The supernatant was taken from broth culture by filtration. The bacterial culture was inactivated by adding $0.4 \%(\mathrm{v} / \mathrm{v})$ formalin (Watson and Davies, 1993 ), at $37^{\circ} \mathrm{C}$ for $24-48 \mathrm{~h}$ with agitation for $24 \mathrm{hrs}$, Then, sodium bisulfite was added in a final concentration of $2 \%$ to stop the action of formalin. Samples from inactivated bacterial culture were tested for complete inactivation by cultivated on BHI agar media to assure complete inactivation where no growth was found on any of the inoculated media after incubation at $37 \mathrm{C}$ for $24 \mathrm{~h}$ to 7 days of incubation, according to OIE (2014).

\section{Determination of the Minimum Lethal Dose (MLD) of Staphylococcus aureus filtrate in mice}

Double fold serial dilutions of the $S$. aureus filtrate were prepared in PBS, $0.1 \mathrm{ml}$ of each dilution was injected into each of three experimental mice weighting about 25 grams. Mice were kept under observation for 3 days post inoculation and the MLD (which is the minimum amount of toxin that killed all mice in 3 days) was determined according to Smith (1975) and Smyth (1975).

Vaccine formulation according to (Ahmed 2012)

The inactivated $S$. aureus bacterin and toxoid vaccine was prepared as an oil emulsion vaccine using Montanidetm ISA $71 \mathrm{VG}$ adjuvant (SEPPIC, France) in a ratio of 71 adjuvant: 29 antigen. Merthiolate (Thiomersal) was used in a final concentration of 1: 10,000 as a preservative. The dose of the prepared vaccine was $0.5 \mathrm{ml}$ contain $1 \times 109$ CFU and MLD50 of toxoid.

\section{Quality control of the prepared Staphylococcus aureus vaccine}

The prepared $S$. aureus inactivated oil emulsion vaccine was tested for sterility test, safety test, complete inactivation and potency according to the Standard International Protocols as described by the OIE (2017).

\section{Experimental design}

One hundred and sixty, 1-day-old SPF chickens were obtained from Nile- SPF farm, KomOshim project, El-Fayoum Governorate, Egypt. The chickens were housed in SPF isolator units in specific CLEVB animal care building with water and feed provided ad-libitum. At 
3 weeks of age, blood samples were collected for serological examination to insure their freedom from maternally derived antibodies against $S$. aureus, 3 weeks old SPF broiler chickens were divided into 3 groups, chickens of group (1) of 80 birds injected S/C with $0.5 \mathrm{ml}$ of previously prepared oil adjuvanted S. aureus vaccine in the middle part of the neck two times with 3 weeks intervals, the groups 2 and 3 ,each group consisted of 40 birds, as control positive and negative groups wereleft unvaccinated.

Serum samples were obtained regularly from vaccinated and unvaccinated groups before immunization, weekly for 3 weeks after the primary vaccination and every week post boostering for 6 weeks, and stored at -20 ${ }^{\circ} \mathrm{C}$ untill used.

\section{Challenge test}

Birds of groups 1 and 2 were challenged 4 weeks after the booster dose by oral administration of $1 \mathrm{ml}$ of broth culture containing $1 \times 109 \mathrm{CFU}$ of reference $S$. aureus virulent strain obtained from Veterinary Serum and Vaccine Research Institute (VSVRI), Abassia. The inoculated chickens were observed for one month. The degree of protection was assessed according to the severity of the clinical signs, the mortality and the recovery of the challenge organisms from fecal samples were assayed according to Paiva et al. (2009).

\section{Detection of the shedding of Staphylococcus aureus in fecal samples}

One week after the challenge and for 4 weeks, cloacal swabs were collected from each of the infected as well as control groups and examined bacteriologically for the presence of $S$. aureus weekly during one month after challenge according to Ahmed (2012) and Raza et al. (2015). Suspected colonies were identified morphologically and biochemically.

\section{Antibody titers}

Indirect haemagglutination test for measuring antibody titers in vaccinated chickens were done according to Rahman et al. (2005).

\section{RESULTS}

Isolation and identification of Staphylococcus aureus field isolates

Out of a total number of 78 samples were collected from infected chicken showing clinical signs of planter abscess or bumble foot, ten locally field isolates were detected and confirmed phenotypically by culturing, Gram staining, biochemical and molecular identification to be $S$. aureus in prevalence of (12.82\%). Gram's staining revealed that the colonies morphology of $S$. aureus were small to medium sized and golden yellow on BHI agar, while the colonies appeared surrounded by a double zone of beta haemolysis on blood agar plates, on mannitol salt agar, they were yellow color surrounded by yellow halo with yellow colored medium the colonies were typically black smooth with entire margin on Baird Parker agar media.

Phenotypic characterization of some virulence factors as haemolysin production assay and coagulase production.

All ten $S$. aureus isolates were coagulase positive and produce bata hemolysis.

\section{Molecular identifiction of $C l f A$ and $b l a Z$ genes of Staphylococcus aureus isolates}

The PCR amplification with ClfA specific primers was conducted with genomic DNA, which resulted in a product of approximate size 638bp (Figure 1).ClfA gene was found in all ten (100\%) S. aureus isolates. The PCR amplification with blaZ gene specific primers was conducted with genomic DNA, resulted in a product of approximate size $833 \mathrm{bp}$ (Figure 2). BlaZ gene was present in ten $(100 \%) S$. aureus isolates. Sequence identities between the isolated Egyptian strain ( $S$. aureus ASM strain)and different $S$. aureus strains uploaded from GenBank revealed that $99.5 \%$ to $100 \%$ homology. Sequence identities between the Egyptian isolated strain (S. aureus ASM strain)and different $S$. aureus strains uploaded from GenBank revealed that $96.1 \%$ to $98.9 \%$.

Quality control of the preperaed Staphylococcus aureus vaccine

assured that the locally prepared vaccine free from any bacterial (aerobic or anaerobic contaminants) or fungul contamination and safe as there was no local reaction found in all injected chickens.

\section{Antibody titers in vaccinated chickens}

The results of humoral immune response revealed that the geometric mean antibody titers against $S$. aureus values of both groups as shown in table 3. The GMT antibody titer was (16) in the $1^{\text {st }}$ week post vaccination, 
and increase gradually at the $2^{\text {nd }}$ week $(20.16)$, till reach to maximum level at $6^{\text {th }}$ week was $(322.5)$ as shown in Table 3 .

\section{Challenge test}

The vaccine showed a considerable survival rate in challenged vaccinated group compared to control group. The mortality rates and survival percentages in groups control and vaccinated are summarized in table 4 , the NO. of dead chickens in the $1^{\text {st }}$ week post challenge in the control and vaccinted group were $17(42.5 \%)$ and 3 $(7.5 \%)$, respectively. The mortality rate in the $2^{\text {nd }}$ week in the control group $9(39.1 \%)$ and vaccinated group 2 $(5.4 \%)$. Protection or survival (\%) till day 7 post challenge $(20 \%)$ in control group and vaccinated group
$(92.5 \%)$. Protection or survival (\%) till 15 day post challenge $(0 \%)$ in control group and (87.5\%) in vaccinated group as shown in table 4 . The challenge protection assay showed a considerable protective immune response of prepared $S$. aureus vaccine.

\section{Detection of the shedding of Staphylococcus aureus in fecal samples}

The results in Table 5 showed that the fecal shedding of chickens challenged with virulent $S$. aureus strain in group 1 vaccinated with locally prepared oil adjuvanted $S$. aureus vaccine was $10.8 \%, 8.5 \%$ and $0 \%$ in $1^{\text {st }}, 2^{\text {nd }}, 3^{\text {rd }}$ week post challenge, respectively. Shedding disappeared by the $4^{\text {th }}$ week post challenge.

Table 3.Geometricmean of Staphylococcus aureus antibody titers in sera of chickens vaccinated with locally prepared oil adjuvanted $S$. aureus vaccine and non-vaccinated groups measured by indirect haemagglutination test.

Time intervals

Pre-vaccination

$1^{\text {st }}$ wpv

$2^{\text {nd }}$ wpv

$3^{\text {rd }}$ wpv

$1^{\text {st }} \mathrm{wpb}$

$2^{\text {nd }} \mathrm{wpb}$

$3^{\text {rd }} \mathrm{wpb}$

$4^{\text {th }} \mathrm{wpb}$

$5^{\text {th }}$ wpb

$6^{\text {th }} \mathrm{wpb}$

wpv: week post-vaccination; wpb: week post-boostering

\section{Geometric mean anti-S. aureus antibody titers}

0

16

20.16

32

40.3

50.79

161

256

256

322.5

Table 4.Comparison ofmortality ratein chicken groupsunvaccinated and vaccinated with the locally prepared oil adjuvantedStaphylococcus aureus vaccine post challenge with virulent reference Staphylococcus aureus strain

\begin{tabular}{|c|c|c|c|c|c|c|c|c|c|}
\hline \multirow[b]{2}{*}{ Groups } & \multirow[b]{2}{*}{ Total birds } & \multicolumn{4}{|c|}{ No. of dead birds } & \multicolumn{3}{|c|}{ Mortality rate } & \multirow[b]{2}{*}{ Total } \\
\hline & & $\begin{array}{c}1^{\text {st }} \\
\text { wpc }\end{array}$ & $2^{\text {nd }}$ wpc & $3^{\text {rd }}$ wpc & $\begin{array}{c}4^{\text {th }} \\
\text { wpc }\end{array}$ & $\begin{array}{c}\mathbf{1}^{\text {st }} \\
\text { week }\end{array}$ & $\begin{array}{c}2^{\text {nd }} \\
\text { week }\end{array}$ & $\begin{array}{c}\mathbf{3}^{\text {rd }} \\
\text { week }\end{array}$ & \\
\hline Vaccinated & 40 & 3 & 2 & 0 & 0 & $7.5 \%$ & $5.4 \%$ & $0 \%$ & $12.5 \%$ \\
\hline Unvaccinated & 40 & 17 & 9 & 8 & 3 & $42.5 \%$ & $39.1 \%$ & $57.1 \%$ & $92.5 \%$ \\
\hline
\end{tabular}

wpv: week post- challenge

Table 5.Comparison of rate offecalshedding in chicken groupsunvaccinated and vaccinated with the locally prepared oil adjuvantedStaphylococcus aureus vaccinepostchalleng with virulent reference Staphylococcus aureus strain

\begin{tabular}{|c|c|c|c|c|}
\hline \multirow{2}{*}{ Groups } & \multicolumn{4}{|c|}{ No. of birds positive for $S$. aureus isolation/ total No. of living birds } \\
\hline & $1^{\text {st }}$ wpc & $2^{\text {nd }}$ wpc & $3^{\text {rd }}$ wpc & $4^{\text {th }}$ wpc \\
\hline Vaccinated & $\begin{array}{l}10.8 \% \\
(4 / 37)\end{array}$ & $\begin{array}{c}8.5 \% \\
(3 / 35)\end{array}$ & $\begin{array}{c}0 \% \\
(0 / 35)\end{array}$ & $\begin{array}{c}0 \% \\
(0 / 35)\end{array}$ \\
\hline Unvaccinated & $\begin{array}{l}47.8 \% \\
(11 / 23)\end{array}$ & $\begin{array}{l}57.1 \% \\
(8 / 14)\end{array}$ & $\begin{array}{c}33.3 \% \\
(2 / 6)\end{array}$ & $\begin{array}{c}33.3 \% \\
(1 / 3)\end{array}$ \\
\hline
\end{tabular}

wpv: week post- challenge 


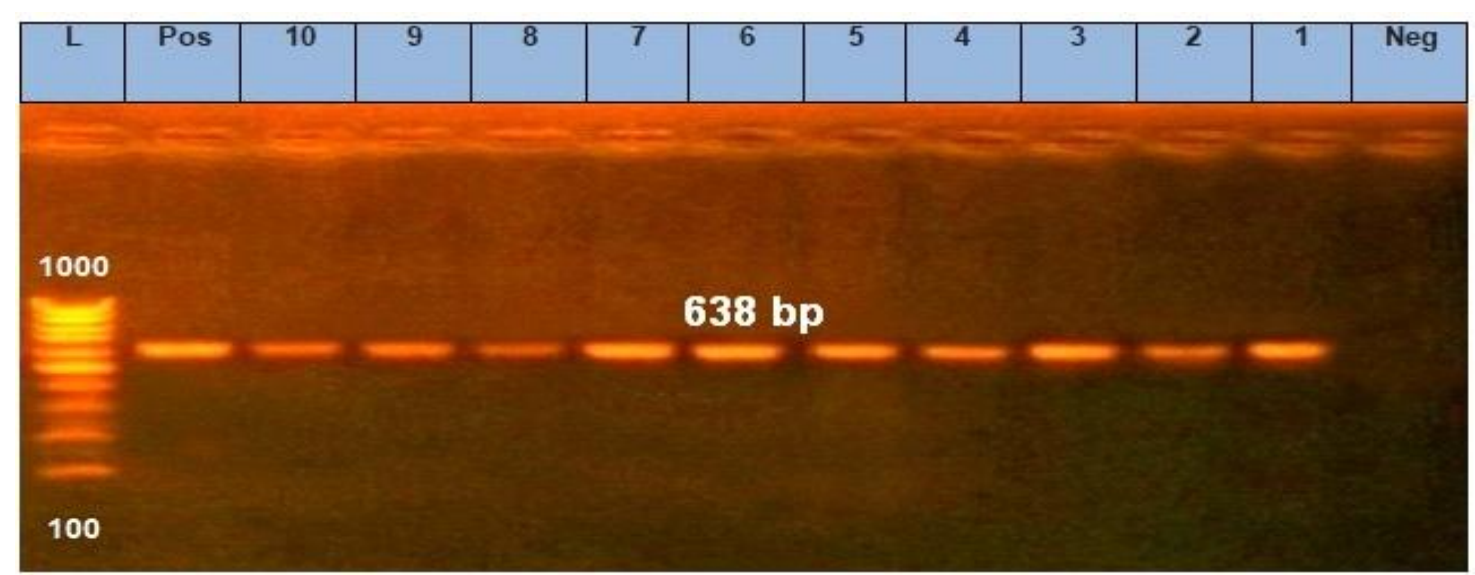

Figure 1. Agarose gel showing PCR amplified product of 638 bp of clumping factor A (ClfA) virulence gene for Staphylococcus aureus, lanes (1) to (10): samples positive for ClfA gene, Lane (Pos.): positive control, Lane (Neg.): Negative control, Lane (L): MW 100bp ladder (DNA marker).

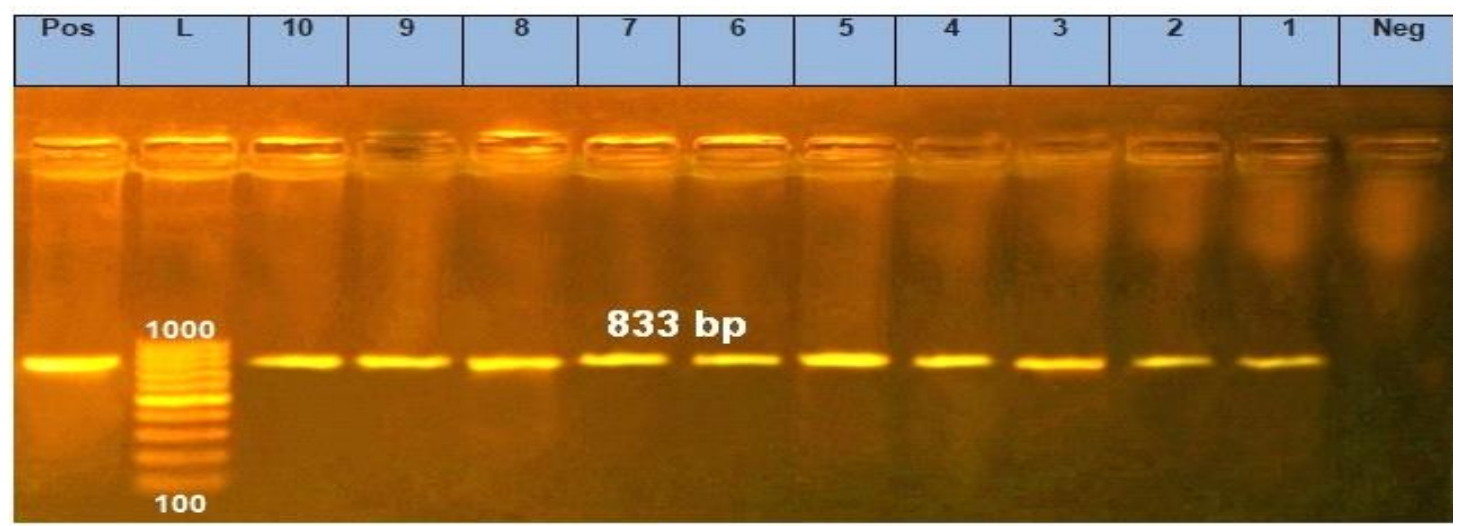

Figure 2. Agarose gel showing PCR amplified product of $833 \mathrm{bp}$ of $\beta$-lactamase resistant (Blaz) gene for Staphylococcus aureus, lanes (1) to (10): samples positive for Blaz gene, lane (pos.): positive control, lane (Neg.): Negative control, Lane (L): MW 100bp ladder (DNA marker).

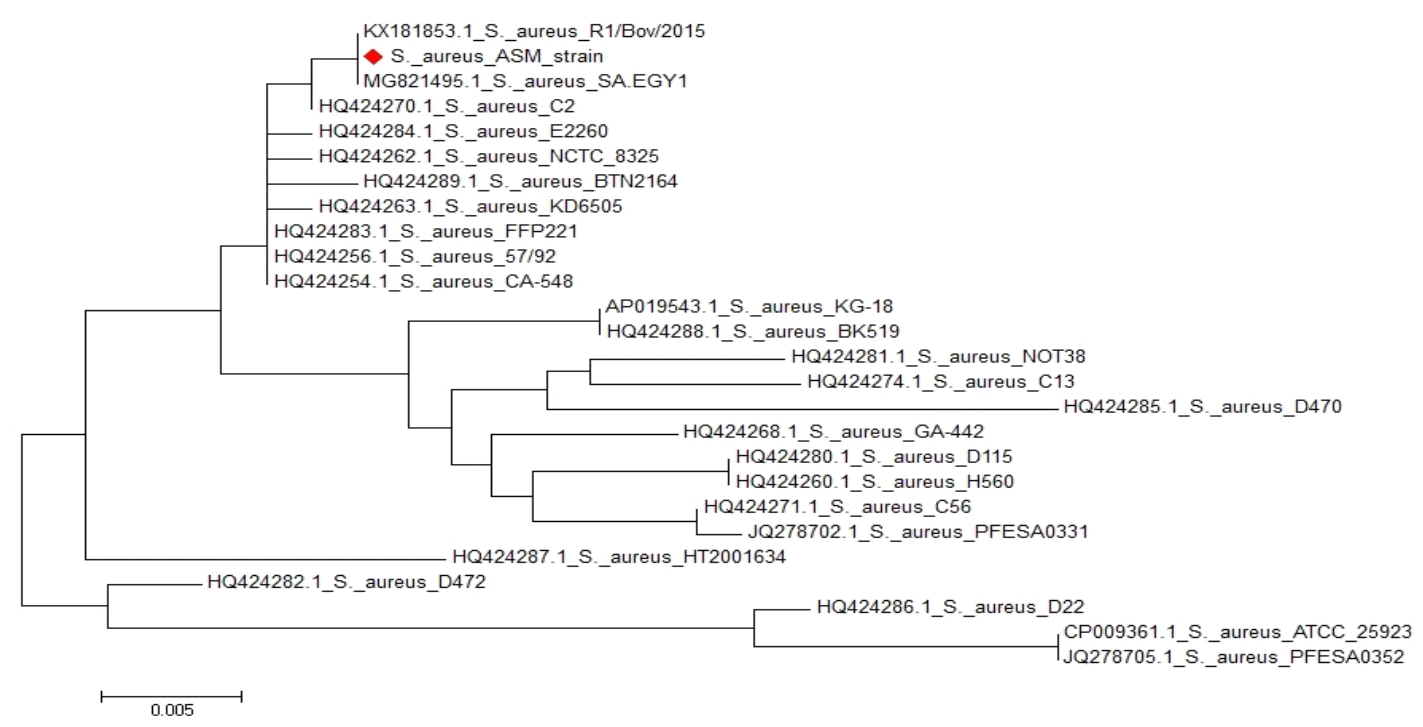

Figure 3. Phylogenetic tree for Staphylococcus aureusclumping factor A (ClfA) virulence gene partial nucleotide sequences that was generated using maximum likelihood, neighbor joining and maximum parsimony in MEGA6. It shows clear clustering of the Egyptian isolated strain (S. aureus ASM strain) and different S. aureus strains uploaded from GenBank. 


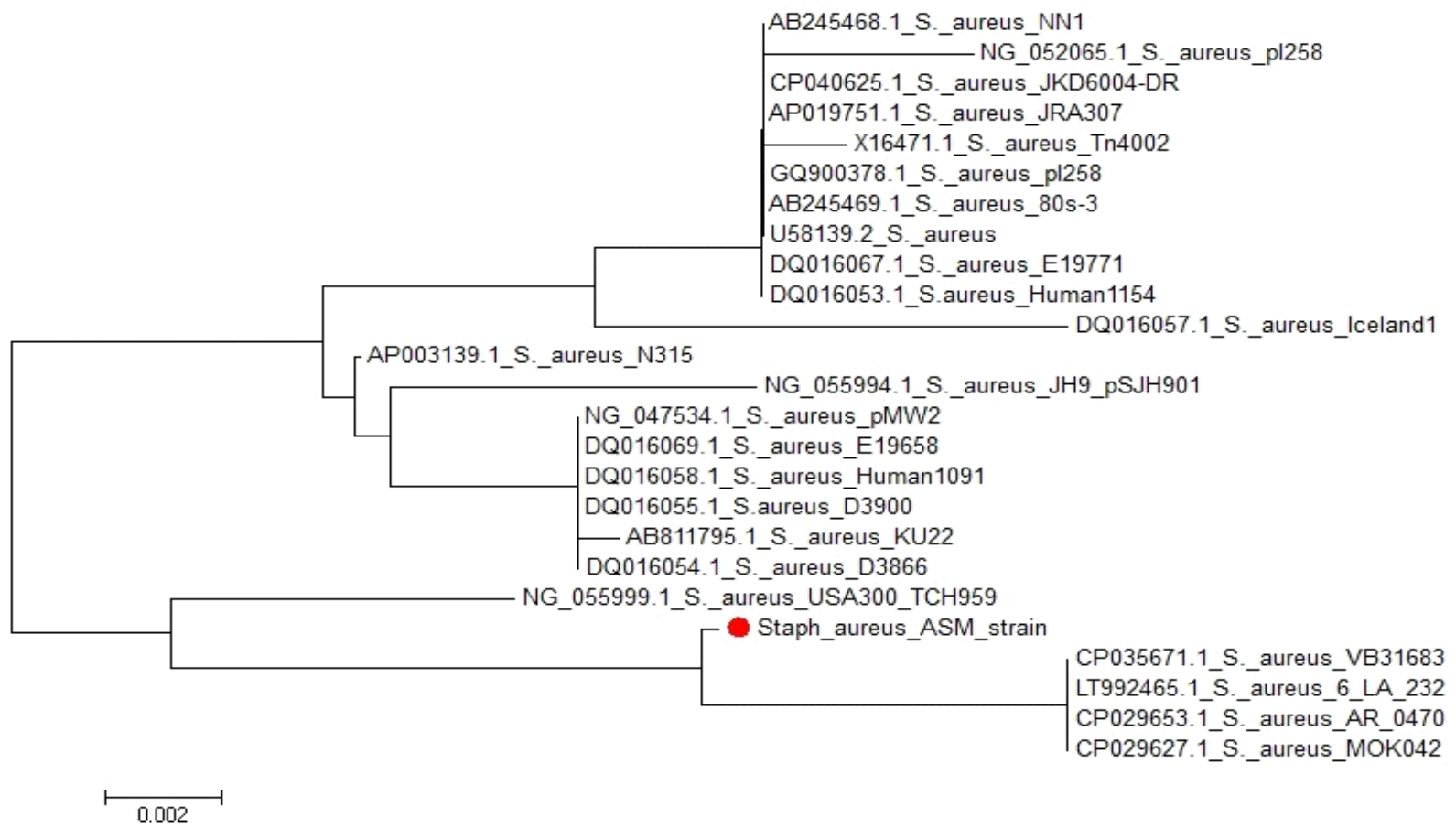

Figure 4. Phylogenetic tree for Staphylococcus aureus $\beta$-lactamase (Blaz) resistant gene partial nucleotide sequences that was generated using maximum likelihood, neighbor joining and maximum parsimony in MEGA6. It showed clearclustering of the Egyptian isolated strain (S. aureus ASM strain) and different S. aureus strains uploaded from GenBank.

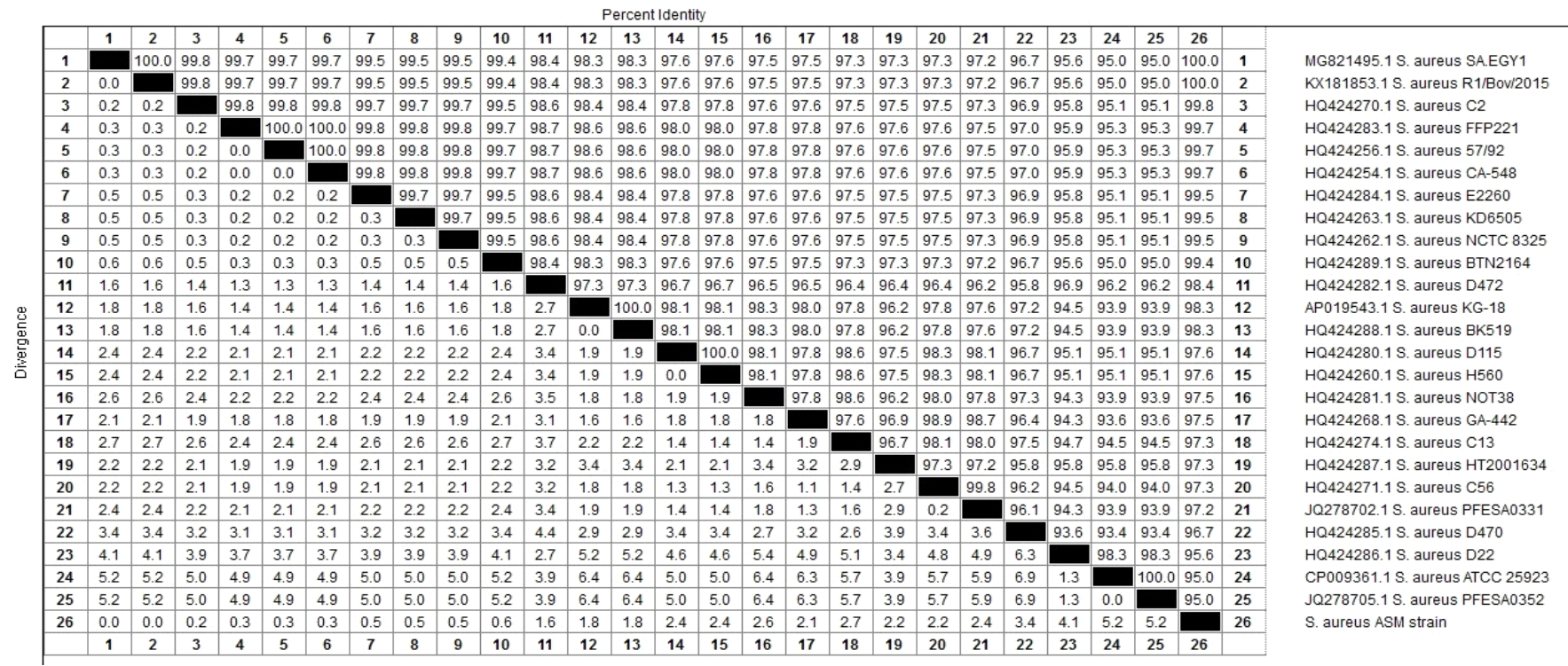

Figure 5. Nucleotide sequence distance of Staphylococcus aureusclumping factor A (ClfA) virulence gene between the Egyptian isolated strain (S. aureus ASM strain) and different $S$. aureus strains uploaded from GenBank 
El-Maghrabyet al., 2020

Percent Identity

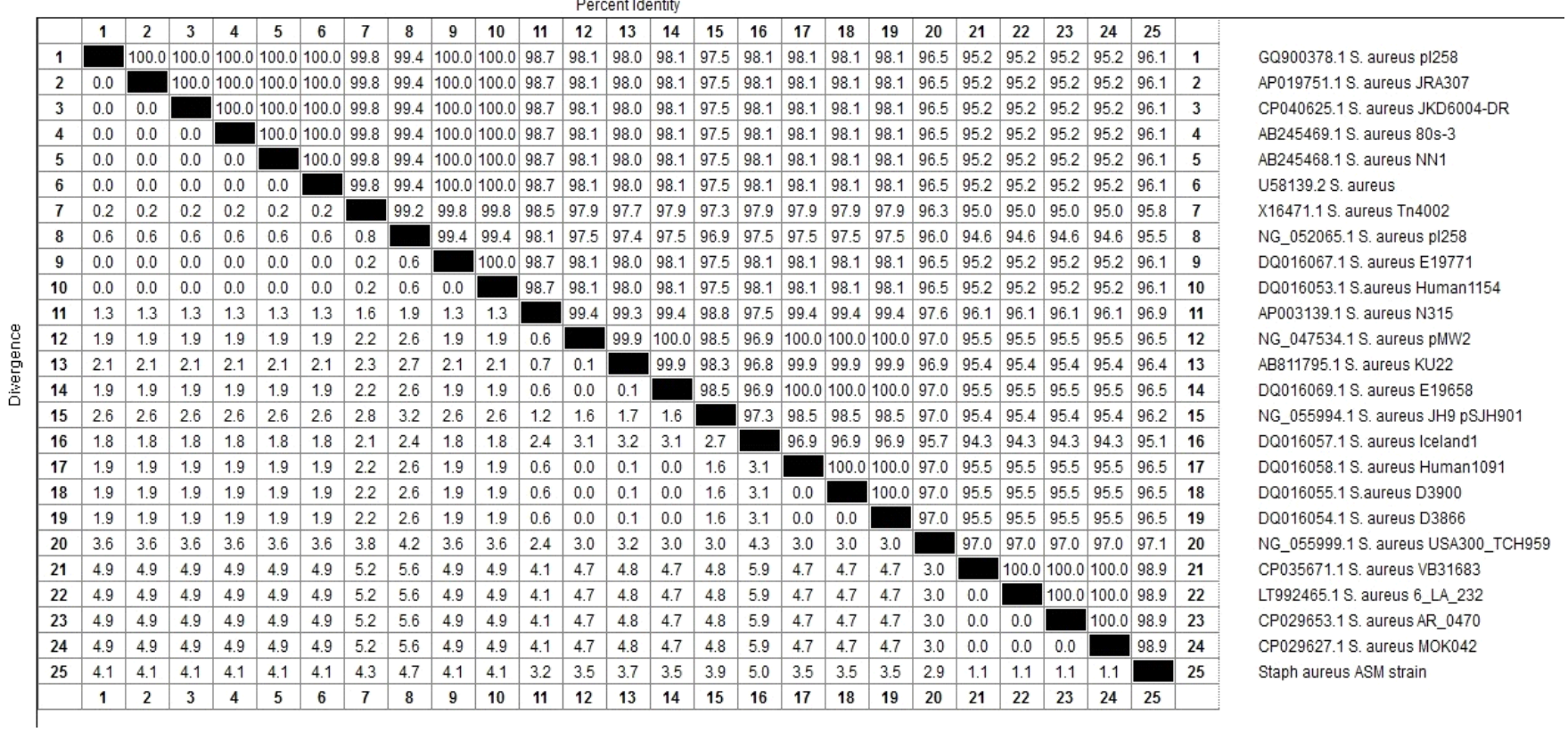

Figure 6. Nucleotide sequence distance of Staphylococcus aureus $\beta$-lactamase (Blaz) resistant gene between the Egyptian isolated strain (S. aureus ASM strain) and different $S$. aureus strains uploaded from GenBank

\section{DISCUSSION}

Among the most important diseases of poultry, S. aureus infection, also called bumble foot, is a common bacterial disease of commercial broilers and layers. It causes significant economic losses through mortality $(0-15 \%)$ and reduce production performance of birds. Out of a total number of 78 samples were collected from infected chicken showing clinical signs of planter abscess or bumble foot, ten locally field isolates were detected and confirmed phenotypically by culturing, Gram staining, biochemical and molecular identification to be $S$. aureus in prevalence of $(12.82 \%)$, this findings agree with Marek et al. (2016) (15.89\%) and disagree with Mamzaet al. (2010) (52.5\%), (Suleiman et al., 2013) (54\%), Abd ElTawab et al. (2017) (66\%), Rasheed (2011) (50.98\%). The colonies morphology of $S$. aureus were small to medium sized and golden yellow on BHI agar, while the colonies appeared surrounded by a double zone of beta haemolysis on blood agar plates, on mannitol salt agar, they were yellow color surrounded by yellow halo with yellow colored medium the colonies were typically black smooth with entire margin on Baird Parker agar media. For the biochemical results, strains revealed that all were identified as $S$. aureus as shown in table 2. This finding was in accordance with the findings of Topley and Wilson (1990), Selim et al. (1984) and Paul et al. (2014).

Phenotypic characterization of some virulence factors as haemolysin production assay and coagulase production. All ten $S$. aureus isolates were coagulase positive and produce bata hemolysis, these two factors are important in phagocytosis and infection due to toxins production respectively (Bhanderi et al., 2009 and Cariolato et al., 2008).

Molecular identifiction of ClfA and blaZ genes of $S$. aureus isolates revealed that the PCR amplification with $C l f A$ specific primers was conducted with genomic DNA, which resulted in a product of approximate size 638bp. clumping factor A (ClfA) gene was found in all ten (100\%) S. aureus isolates these results agree with Nemati et al., (2009) (100\%), Erfan and Marouf (2015) (100\%) and disagree with Mohamed A. Lebdah et al., (2015) (20\%). S. aureus expresses several different proteins including clumping factors A (ClfA) that play an important role in the ability of $S$. aureus to cause disease Perkins et al., (2001) and Walsh et al., (2008). Clumping factor A (ClfA) is a microbial surface protein that promotes $S$. aureus binding to fibrinogen, and is associated with septic arthritis and infective endocarditis Elkhatib et al., (2015). The PCR amplification with blaZ gene specific primers was conducted with genomic DNA, resulted in a product of approximate size 833 bp.blaZ gene was present in ten (100\%) S. aureus isolates these finding nearly agree with Bakheet et al. (2018) (74\%) and disagree with Ganugula Mohana Sheela (2017) (57.69\%).

Phylogenetic and partial gene sequence analysis of ClfAandblaZ genes of $S$. aureus that was generated using maximum likelihood, neighbour joining and maximum 
parsimony in MEGA6, showed clear clustering of isolated Egyptian strain ( $S$. aureus ASM strain) and different $S$. aureus strains uploaded from GenBank. Sequence distance of S. aureus ClfA virulence gene (Figure 3) was created by the MegAlign module of Laser gene DNA Star. Sequence identities between the isolated Egyptian strain (S. aureus ASM strain) and different $S$. aureus strains uploaded from GenBank (Figure 5) revealed that $99.5 \%$ to $100 \%$ homology. When analyzing nucleotide sequence of ClfA gene of the Egyptian isolated strain ( $S$. aureus ASM strain) in the current study showed 100\% nucleotide identity with locally isolated Egyptian $S$. aureus strain SA.EGY1 recovered by Erfan and Marouf (2018) (accession No. MG821495.1). The Egyptian isolated strain (S. aureus ASM strain) showed also 100\% identity with the indianS. aureus strain R1/Bov/2015 by Vaidya et al., (2016) (GenBank accession No. KX181853.1). Also showed 99.8\% identity with the American S. aureus strain C2 by Murphy et al., (2011) (GenBank accession No. HQ424270.1), and showed 99.7\% identity with the American S. aureus strain FFP221 by Murphy et al. (2011) (GenBank accession No. HQ424283.1), American S. aureus strain $57 / 92$ by Murphy et al. (2011) (GenBank accession No. HQ424256.1) and American S. aureus strain CA-548 (GenBank accession No. HQ424254.1). Concerning S. aureus blaZ gene nucleotide sequence analysis revealed great homology and identity between the Egyptian isolated strain (S. aureus ASM strain) and the different $S$. aureus strains uploaded from GenBank. Phylogenetic tree for S. aureus blaZB-lactamase resistant gene (Figure 4) partial sequences showed clear clustering of the Egyptian isolated strain ( $S$. aureus ASM strain) and different $S$. aureus strains uploaded from GenBank. Figure 6 shows that sequence distance of $S$. aureus blaZantibiotic resistant gene was created by the MegAlign module of Laser gene DNA Star. Sequence identities between the Egyptian isolated strain (S. aureus ASM strain) and different $S$. aureus strains uploaded from GenBank revealed that $96.1 \%$ to $98.9 \%$. When analyzing nucleotide sequence of blaZ B-lactamase resistant gene of the Egyptian isolated strain ( $S$. aureus ASM strain) in the current study it showed $98.9 \%$ identity with the Ireland $S$. aureus MOK042 strain recovered by Keane and Cormican 2018), (GenBank accession No. CP029627.1), the American S. aureus strain AR_0470 recovered by Benahmed et al., (2018) (GenBank accession No. CP029653.1) and the German S. aureus isolate 6_LA_232 recoverd by Schleimer et al. (2018) (GenBank accession No. LT992465.1).
Quality control of the prepared $S$. aureus vaccine assured that the locally prepared vaccine free from any bacterial (aerobic or anaerobic contaminants) or fungal contamination and safe as there was no local reaction found in all injected chickens.

The results of humoral immune response revealed that the geometric mean antibody titers against $S$. aureus values of both groups as shown in table 3. The GMT antibody titer was (16) in the $1^{\text {st }}$ week post vaccination, and increase gradually at the $2^{\text {nd }}$ week (20.16), till reach to maximum level at $6^{\text {th }}$ week was (322.5) as shown in Table 3. These finding agree with (Raza et al., 2015). The vaccine showed a considerable survival rate in challenged vaccinated group compared to that of control group. The mortality rates and survival percentages in groups control and vaccinated are summarized in table 4, the NO. of dead chickens in the $1^{\text {st }}$ week post challenge in the control and vaccinated group were $17(42.5 \%)$ and 3 (7.5\%), respectively. The mortality rate in the $2^{\text {nd }}$ week in the control group 9 (39.1\%) and vaccinated group 2 (5.4\%). Protection or survival (\%) till day 7 post challenge (20\%) in control group and vaccinated group (92.5\%). Protection or survival (\%) till 15 day post challenge (0\%) in control group and $(87.5 \%)$ in vaccinated group as shown in Table 4. The challenge protection assay showed a considerable protective immune response of prepared $S$. aureus vaccine. The findings were in agreement with Giraudo et al. (1997) and Ahmad and Muhammad (2008) with significantly higher survival percentage in vaccinated group compared to that of in control group. The results of challenge protection assay suggested that vaccine is capable of eliciting protective immune response and prevent further new infections of $S$. aureus. Fecal shedding post challenge was also significantly reduced in the vaccinated chickens compared with those in the unvaccinated suggesting that the vaccine could be effective against $S$. aureus. Table 5 showed that the fecal shedding of chickens challenged with virulent $S$. aureus strain in group 1 vaccinated with locally prepared oil adjuvantedS. aureus vaccine was $(10.8 \%, 8.5 \%$ and $0 \%)$ in $1^{\text {st }}, 2^{\text {nd }}, 3^{\text {rd }}$ week post challenge, respectively. Shedding disappeared by the $4^{\text {th }}$ week post challenge. These results agree with previous studies showed that bacterin-toxoid prevent development of new $S$. aureus infection probably due to increased opsonization, increased phagocytic activity of polymorphonuclear cells as a result of augmented specific IgG antibodies against S.aureus (Pellegrino et al., 2010 and Raza et al., 2015). From this study it could be concluded that the locally prepared vaccine was safe, potent and could be recommended to be used in poultry farms to prevent $S$. aureus infections in chicken. 


\section{DECLARATIONS}

\section{Acknowledgments}

This study was supported by the Central Laboratory for Evaluation of Veterinary Biologics (CLEVB), Abbasia, Cairo and Veterinary Serum and Vaccine Research Institute (VSVRI), Abbasia, Cairo, Egypt.

\section{Competing interests}

The authors have declared that no competing interest exists.

\section{Authors' contribution}

Abeer El-Maghraby designed the concept of the article, wrote the manuscript. SherenAzez and AbeerMwafy prepared the vaccine. AbeerMwafy revised the manuscript. All authors designed and performed the experiments and reviewed and approved the manuscript.

\section{REFERENCES}

Abd El-Tawab A, Fatma I Hofy, Sahar R Mohamed and Sohila H Amin (2017). Characterization of methicillin resistance Staphylococcus aureus isolated from chicken and human. Benha University Medical Journal, 32 (1): 132- 137.Available at: http://www.bvmj.bu.edu.eg

Ahmad T and Muhammad G (2008). Evaluation of Staphylococcus aureus and Streptococcus agalactiaealuminum hydroxide adjuvanted mastitis vaccine in rabbits. Pakistan Journal Agricultural Science, 45: 353-361. Available at: http://agris.fao.org/agrissearch/search.do?recordID=PK2009000420

Ahmed Mohamed Osman Abd El-Karim (2012). Studies on preparation, standardization and evaluation of Staphylococcus aureus vaccine in poultry.Ph.D. thesis.Department of Microbiology, Faculty of Veterinary Medicine, Cairo University.

Altschul SF, Gish W, Miller W, Myers EW and Lipmanl DJ (1990). Basic local alignment search tool. Journal Molecular Biology, 215: 403410. DOI: https://doi.org/10.1016/S0022-2836(05)80360-2

Bagcigil AB, Taponen S, Koort J, Bengtsson B, Myllyniemi A and Pyörälä S(2012). Genetic basis of penicillin resistance of $S$. aureus isolated in bovine mastitis.ActaVeterinariaScandinavica, 54: 69. DOI: https://doi.org/10.1186/1751-0147-54-69

BakheetAml A, Amen Omar Habaty, Sayed HAL, DarwishSamah F (2018). Prevalence of Staphylococcus aureusin broiler chickens with special reference to beta-lactam resistance genes in the isolated strains. Alexandria Journal for Veterinary Sciences, 57 (2): 25-33.

Benahmed FH, Lutgring JD, Yoo B, Machado M, Brown A, McAllister G, Perry A, Halpin AL, VavikolanuK, Ott S, Zhao X, Tallon LJ, Sadzewicz L, Aluvathingal J, Nadendla S, Voskania-kordi A, Simonyan V, Patel J and Shawar RM (2018). Direct Submission Journal Submitted (24-MAY-2018), Center for Devices and Radiological Health, US Food and Drug Administration, 10903 New Hampshire Avenue, Silver Spring, MD 20993-0002, USA.

Bhanderi BB, Roy A, Yadav MM and Joshi CG (2009). PCR based detection of virulence associated genes of Staphylococcus aureus from clinical and subclinical bovine mastitis. Royal Veterirnary Journal of India, 5(1/2), 20-26. Available at: https://www.researchgate.net/publication/40904878

Cariolato D, Andrighetto C and Lombardi A (2008). Occurrence of virulence factors and antibiotic resistance in Enterococcus faecalisand Enterococcus faecium collected from dairy and human samples in North Italy. Food Control, 19: 886-892.DOI: https://doi.org/10.1016/j.foodcont.2007.08.019
El-Jakee JK, Noha E. Aref, AlaaGomaa, Mahmoud D El-Hariri, Hussein M Galal, Sherif A Omar, Ahmed Samir (2013). Emerging of coagulase negative staphylococci as a cause of mastitis in dairy animals: An Environmental hazard.International Journal of Veterinary Science and Medicine. 1: 74-78. DOI: https://doi.org/10.1016/j.jivsm.2013.05.006

Elkhatib WF, Hair PS, Nyalwidhe JO and Cunnion KM (2015). New potential role of serum apolipoprotein $\mathrm{E}$ mediated by its binding to clumping factor A during Staphylococcus aureus invasive infections to humans. Journal Medical Microbiolgy, 64: 335-343. DOI: https://doi.org/ 10.1099/jmm.0.000010

Erfan AM and Marouf SH (2015). Biofilm-producing Staphylococcus aureus screening in poultry farms and abattoirs. Journal of Animal and Veterinary Advances, 14 (10): 273-279. Available at: https://www.researchgate.net/publication/301849264

Erfan AM and Marouf SH (2018). Molecular characterization of bacterial respiratory disease in poultry, regarding the effect of cinnamon oil submitted reference laboratory for veterinary quality control on poultry production, Animal health research institute, Nadi Elseidstreet, Dokki, Giza 12618, Egypt.

Fluit AC (2012). Livestock- associated Staphylococcus aureus. Clinical.Microbiology and Infection,18: 735-744.DOI: https://doi.org/10.1111/j.1469-0691.2012.03846.x

GanugulaMohana Sheela (2017). Study of pathogenic factors of Staphylococcus aureus from clinical cases of livestock and poultry. $\mathrm{PhD}$. Thesis, Department of Biotechnology, Vignan's Foundation for Science Technology and Research Univerisity, Vadlamudi Guntur, Andhra Pradesh, India.Available at: https://vignan.ac.in/pdf/Mohana\%20Sheela.pdf

Giraudo JA, Calzolari A, Rampone H, Rampone A, Giraudo AT, Bogni C, Larriestra A and Nagel R (1997). Field trials of a vaccine against bovine mastitis. 1. Evaluation in heifers. Dairy Science, 80: 845853.DOI:http://10.3168 /jds. S0022-0302(97)760065.DOI: https://doi.org/10.3168/jds.S0022-0302(97)76006-5

Jordan F, Pattison M, Alexander D, Faragher T (2002). Poultry diseases. $5^{\text {th }}$ editon. London: W. B. Saunders. p. 163. Available at:www.chegg.com , textbooks, poultry-diseases-5th-edition9780702.

Kateete DP, Kimani CN, Katabazi FA, Okeng A, Okee MS, Nanteza A, Joloba ML and Najjuka FC (2010).Identification of Staph.aureus: DNase and mannitol salt agar improve the efficiency of the tube coagulase test. Annals of .Clinical. Microbiology and Antimicrobials, $\quad 9$ 23. Available at: https://www.ann.clinicrob.com/content/9/1/23

Keane OM and Cormican P (2018). Complete genome sequence of ST71 Staphylococcus aureus isolates from bovine milk Submitted (24MAY-2018) Animal \& Bioscience, Teagasc, Grange, Dunsany, Co Meath N/A, Ireland.

Koneman EW, Allen SD, Janda WM, Schreckenberger PC and WinnJr WC (1997). Color Atlas and Textbook of Diagnostic Microbiology, JB Lippincott, Philadelphia, p.1395

Liu, GY (2009). Molecular Pathogenesis of Staphylococcus aureus .Infection. Pediatric Research., 65: 71-77.DOI: 10.1203/PDR.0b013e31819dc44d

López-Malo A, Vigil E, Palou ME and Parish PM (2005). In: Davidson, Methods for Activity Assay and Evaluation of Results. Davidson P.M, Sofos N.J, Branene A.L, editors. Boca Raton, FL, USA: Antimicrobials in Food, Taylor and Francis Group; pp. 659-680. DOI: http://dx.doi.org/10.1201/9781420028737.ch21

Mamza SA, Egwu GO and Mshelia GD (2010). Antibiotic susceptibility patterns of beta-lactamase-producing Escherichia coli and Staphylococcus aureus isolated from chickens in Maiduguri (Arid zone), Nigeria Veterinary Archive, 80: 283-297. Available at: www.researchgate.net > publication > 228494706

Marek A, Stepień-Pyśniak D, Pyzik E, Adaszek Ł, Wilczyński J and Winiarczyk S (2016). Occurrence and characterization of Staphylococcus bacteria isolated from poultry in Western Poland. 
Berl Munch TierarztlWochenschr, 129 (3-4): 147-52.DOI: http://dx.doi.org/10.2376/0005-9366-129-147

Mason WJ, Blevins JS, Beenken K, Wibowo N, Ojha N and Smeltzer MS (2001).Multiplex PCR Protocol for the Diagnosis of Staphylococcal Infection. Journal of Clinical Microbiology, 39 (9): 3332-3338.DOI: http://dx.doi.org/10.1128/JCM.39.9.3332-3338.2001

Mohamed A. Lebdah, Fatma M. Youssef and Ezz-Eldin (2015).A bacterial leg infections in broiler chickens. Zagazig Veterinary Journal, $\quad 43 \quad$ (3): $\quad 179-188 . \quad$ DOI http://dx.doi.org/10.21608/zvjz.2015.28455

Murphy E, Lin SL, Nunez L, Andrew L, Fink PS, Dilts DA, Hoiseth SK, Jansen KU and Anderson AS (2011). Challenges for the evaluation of Staphylococcus aureus protein based vaccines: Monitoring antigenic diversity Submitted (19-OCT-2010) Pfizer Vaccine Research, 401 N. Middletown Road, Pearl River, NY 10965, USA.

Nemati M, Hermans K, Lipinska U, Denis O, Deplano A, Struelens M (2008). Antimicrobial resistance of old and recent Staphylococcus aureus isolates from poultry: first detection of livestock-associated methicillin-resistant strain ST398. Antimicrobial Agents and Chemotherapy,52 (10): 3817-3819.DOI: http://dx.doi.org/10.1128/AAC.00613-08

NematiM, Hermans K, LucADevriese, DominiekMaes and Freddy Haesebrouck (2009). Screening of genes encoding adhesion factors and biofilm formation in Staphylococcus aureus isolates from poultry. Avian Pathology, 38 (6): 513-517.DOI: http://dx.doi.org/10.1080/03079450903349212.

OIE(2014). Avian Influenza,Manual of Diagnostic Tests and Vaccines for Terrestrial Animals. OIE, Paris, France.Avilableat:https://www.oie.int/doc/ged/D13850

OIE (2017). Terrestrial Animal Health Code. Chapter: 6.5. Prevention, Detection and Control of $S$. aureus in poultry.Avilable at: https://www.oie.int/fileadmin/Home/eng/InternationaStandard_Setti ng/docs/pdf/A_TAHSC_Sept_2017

Paiva JB, Penha FRAC, Arguello YMS, Silva MD, Gardin Y, Resende F, Berchieri Junior A, and Sesti L. (2009). Efficacy of several Salmonella vaccination programs against experimental challenge with Salmonella gallinarumin commercial browen layer and broiler breeder hens. Brazil Journal of Poultry Science, 11(1): 65-72. Avilableat:http://www.scielo.br/pdf/rbca/v11n1/v11n1a10

Paul DP, Isore SN, Joardar SK, Mukhopadhayay and Ganguly S (2014).Pathogenicity test of Staphylococcus sp. by experimental animal inoculation technique. Indian Journal of Comparative Microbiology, Immunology and Infectious Diseases, 35 (2): 9596.DOI: http://dx.doi.org/10.5958/0974-0147.2014.00013.0

Pellegrino M, Giraudo J, Raspanti C, Odierno L and Bogni C (2010).Efficacy of immunization against bovinemastitis using a Staphylococcus aureus avirulent mutantvaccine. Vaccine, 28: 4523$4528 . \quad$ DOI:http:// 10.1016/j.vaccine.DOI: http://dx.doi.org/10.1016/j.vaccine.2010.04.056.

Perkins S, Walsh EJ, Deivanayagam CC, Narayana SV, Foster TJ and Hook M (2001). Structural organization of the fibrinogen-binding region of the clumping factor B MSCRAMM of Staphylococcus aureus.Journal of Biological.Chemistery, 276: 4472144728.DOI:http://dx.doi.org/10.1074/jbc.M106741200

Quinn PJ, Markey BK, Carter ME, Donelly WJ and Leonard FC (2002). Veterinary Microbiology and Microbial Disease. $1^{\text {st }}$ Published A Black well Science Company.Available at: https://www.wiley.com/en-

eg/Veterinary+Microbiology+and+Microbial+Disease\%2C+2nd+Ed ition-

Rahman SU, Athar M, Shakoor A, Muhammad G and Butt AA (2005). Standardization of indirect haemagglutination test for titration of antibody against Staphylococcus aureus, Streptococcus agalactiae and Escherichia coli isolated from bubaline mastitis. Internationl Journal of Agriculture and Biology, 7: 441- 444.
Rasheed BY (2011).Isolation and identification of bacteria causing arthritis in chickens. Iraqi Journal of Veterinary Sciences, 25: 9395.DOI: http://dx.doi.org/10.33899/ijvs.2011.5651

Raza A, Muhammad G, Rahman SU, Rashid I, Hanif K, Atta A and Sharif S (2015). Evaluation of humoral immunity and protective efficacy of biofilm producing Staphylococcus aureusbacterin-toxoid prepared from a bovine mastitis isolate in rabbit. International Journal of Veterinary Resarch, 16 (1): 69-74. Available at: https://www.ncbi.nlm.nih.gov/pmc/articles/PMC4789243/pdf/ijvr16-069

Schleimer N, Van Alen S and Kaspar U (2018).University Hospital Munster, Institute of Medical Microbiology, Muenster, 48149, Germany.

Selim SA, Osman KM, Ismail M, Mohamed SM and Margan SD (1984).Virulence of staphylococci to mice and its relation to lysozyme production and coagulase activity activity. Archive of ExperimentelleVeterinarmedizin, 38 (5) : 692- 696. Available at: https://www.ncbi.nlm.nih.gov/pubmed/6529329

Smith LDS (1975). The Pathogenic Anaerobic Bacteria., $2^{\text {nd }}$ edition. Springfield, Illinois: Charles C. Thomas.

Smyth CJ (1975). The identification and purification of multiple forms of theta-haemolysin (theta toxin) of $C$. perfringens type A. Journal of General Microbiology, 87: 219-238. DOI: http://dx.doi.org/10.1099/00221287-87-2-219

Suleiman A, Zaria LT, Grema HA and AhmaduP(2013). Antimicrobial resistant coagulase positive Staphylococcus aureus from chickens in Maiduguri, Nigeria.Sokoto. Journal of Veterinay Science, 11(1): 5155.DOI:https://dx.doi.org/104134/skojvs.v11i1.8

Tamura K., Stecher G, Peterson D, Filipski A and Kumar S (2013). MEGA6: molecular evolutionary genetics analysis version 6.0. Mol. Biol. $\quad$ Evol., $\quad 30: \quad 2725$ 2729.DOI:http://dx.doi.org/10.1093/molbev/mst197

Taponen S, Bjorkroth J and Pyorala S (2008). Coagulase-negative staphylococci isolated from bovine extramammary sites and intramammary infections in a single dairy herd. Journal of Dairy Research, 75:422429.DOI:http://dx.doi.org/10.1017/S0022029908003312

Thompson JD, Higgins DG and Gibson TJ (1994). CLUSTAL W: improving the sensitivity of progressive multiple sequence alignment through sequence weighting, position-specific gap penalties and weight matrix choice. Nucleic Acids Research, 22(22): 4673-4680.DOI:http://dx.doi.org/10.1093/nar/22.22.4673

Topley CC and Wilson (1990).Principles of Bacteriology, Virology and Immunology. $8^{\text {th }}$ edition. Vol. 3.Edward Arnold Pub. Ltd., 216: 490503

Topley CC and Wilson (1993).Microbiology and Microbial infection. $9^{\text {th }}$ edition. Vol3.WilliamJ.Hasuler Jr.

Vaidya R, Mukherjee R, Chaudhuri P, Chakravarti S, De UK, Dimri U, Kar D, Thakur N, Chandel S and Vikas K (2016). Molecular characterization of Staphylococcus isolates from India Submitted (04-MAY-2016) Veterinary Medicine, ICAR-IVRI, Izatnagar,Bareilly, Uttar Pradesh 243122, India.

Walsh EJ, Miajlovic H, Gorkun OV, and Foster TJ(2008). Identification of the Staphylococcus aureus MSCRAMM clumping factor B (ClfB) binding site in the $\alpha \mathrm{C}$-domain of human fibrinogen. Microbiology, 154: 550-558.DOI:http://dx.doi.org/10.1099/mic.0.2007/010868-0

Watson DL and Davies HI(1993). Influence of adjuvants on the immune response of sheep to a novel Staphylococcus aureus vaccine. Veterinary Microbiology, 34: 139153.DOI:http://dx.doi.org/10.1016/0378-1135(93)901687. 